\title{
A Century of Retreat at Portage Glacier, South-Central Alaska
}

\section{Introduction}

The Portage Glacier, in south-central Alaska, is viewed by thousands of visitors annually who come to the U.S. Forest Service Begich, Boggs Visitor Center located on the road system between Anchorage and Whittier, Alaska. During the past century, the terminus of the glacier has retreated nearly 5 kilometers to its present location (fig. 1). Like other glaciers that terminate in water, such as Columbia Glacier near Valdez or Mendenhall Glacier near Juneau, Portage Glacier has experienced accelerated retreats in recent decades that likely were initially triggered by climate change begun at the end of the Little Ice Age in the mid1800 s and subsequently controlled in recent history primarily by calving of the glacier terminus. Photographic records of the terminus covering 1914 until present day track the patterns of retreat. These data, coupled with USGS climate information collected from the southern end of the ice field, provide insight to the patterns of retreat that might be observed in the future.

\section{History}

During the late 1800 s and early 1900 s, Portage Glacier terminated on land at the western end of Portage Lake, filling Portage Lake with ice (Photo Plate 1914). Since the early 1900s, the glacier has receded, leaving Portage Lake in the scoured basin. The initial retreat of the glacier coincides with known climate warming associated with the end of the Little Ice Age (circa mid- $19^{\text {th }}$ century). As the glacier receded, its land-based terminus retreated into proglacial Portage Lake and changed from its relatively stable land-based environment to an unstable calving environment. The most rapid recession of some 140 to 160 meters per

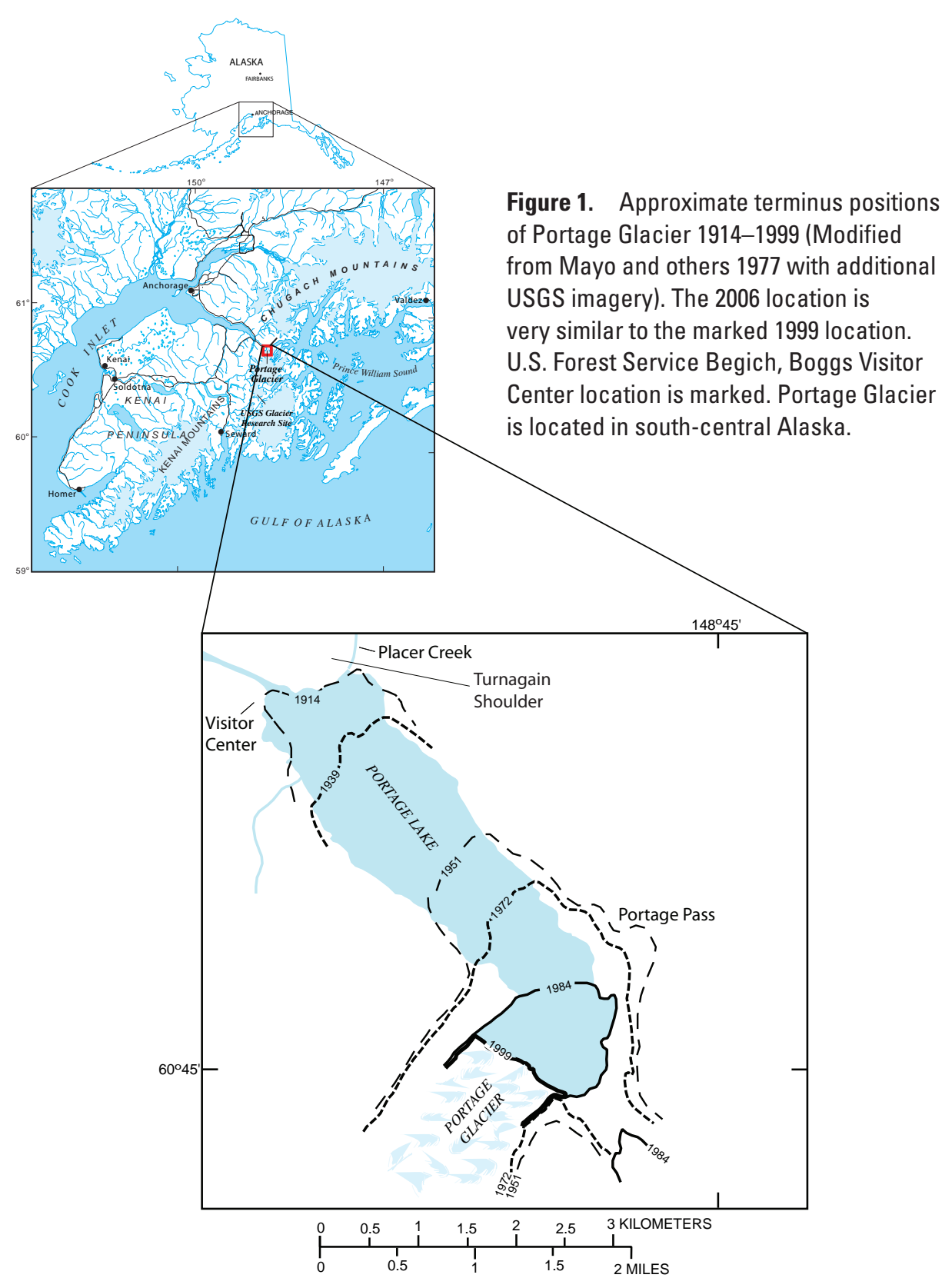

year occurred between 1939 (Photo Plate, 1939) and 1950, when water depth at the terminus was at its maximum-roughly 200 meters. Recession continued through the 1970s and 1980s (Photo Plate, 1972, 1984) until by late 1999 , Portage Glacier had receded almost 5 kilometers, to a more stable position at the eastern end of Portage Lake (Photo Plate, 1999). The retreat was driven primarily by calving of unstable ice at the glacier terminus into Portage Lake. Ice loss resulting from increased melting of the glacier surface during the past century-long general warming trend contributed to glacier retreat, but to a lesser extent. Today, the terminus of Portage Glacier remains close to its 1999 location (Photo Plate, 2006). 


\section{Future Status}

Future changes of the terminus of Portage Glacier will depend on a variety of factors. However, present scientific theory (Meier and Post, 1987, Trabant and others, 2003) suggests that calving glaciers cycle between advance and retreat patterns; with rapid retreats, followed by stable retracted positions, slow advances, and then stable extended positions that are not directly related to climate change. Thus, based on its history to date, and if such a pattern holds for Portage Glacier, the glacier may now be in its stable retracted position and could eventually begin a slow advance. However, for a glacier to advance, annual net balance-the amount of new snow and ice added to the glacier minus the amount of glacier melt-must be positive. As
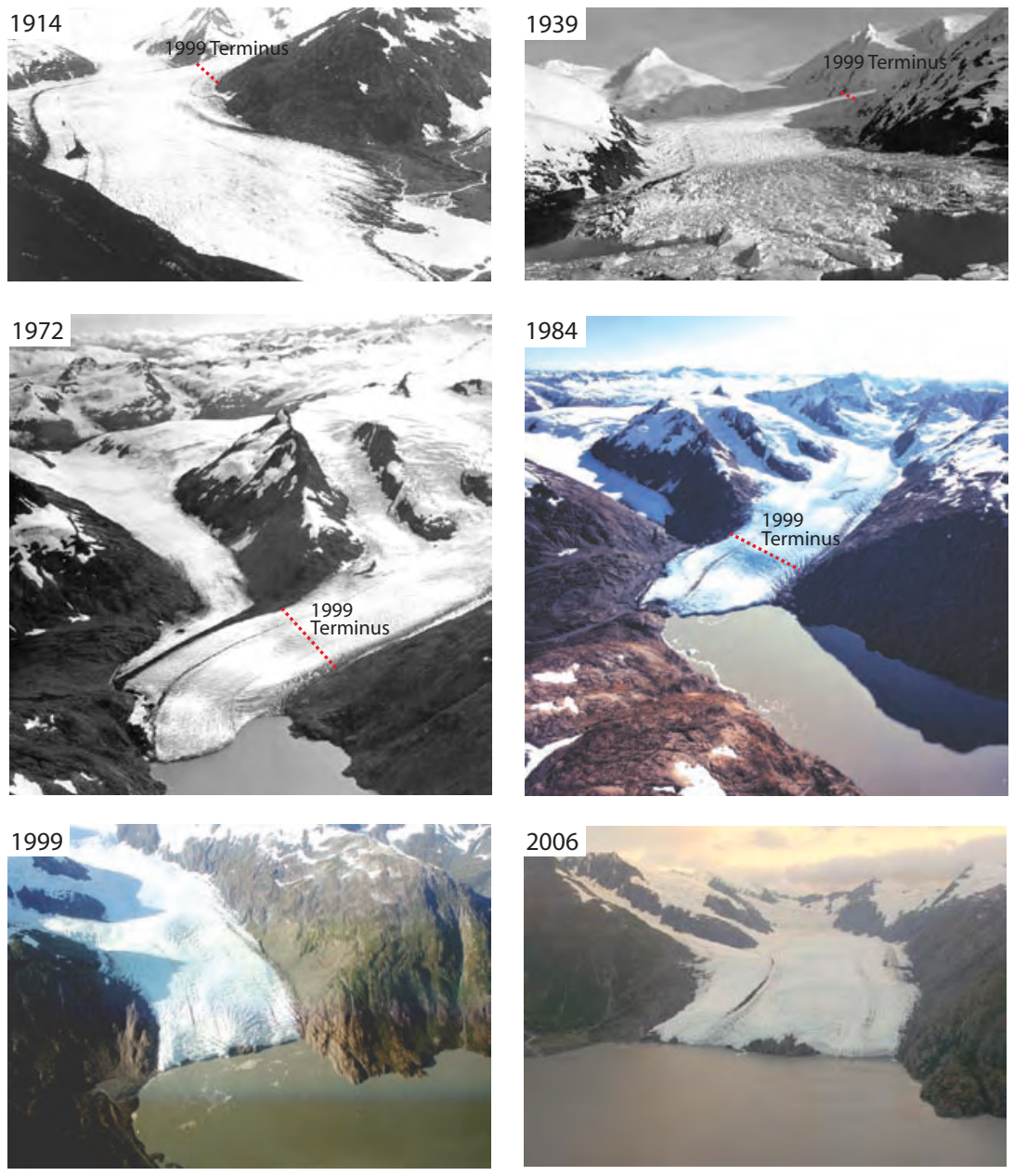

Photo Plate. Series of photographs of the terminus of Portage Glacier. 1914 and 1939 taken from Turnagain Shoulder NW to SE view; 1972 and 1984 oblique aerial view NW to SE; 1999 and 2006 oblique aerial view NE to SW toward Portage Glacier. Photo credits: 1914, Strough http://www.photolib.noaa.gov/historic/c\&gs/images/theb1390.jpg; 1939, Barnes 1943, Plate 17B; 1972, USGS photograph; 1984, Aeromap U.S.; 1999 and 2006, USGS photographs.

\section{Selected References}

Barnes, F.F., 1943, Geology of the Portage Pass area, Alaska: U.S. Geological Survey Bulletin 926-D, p. 211-235.

Crossen, K.J., 1992, Guide to the Little Ice Age landforms and glacial dynamics in Portage Valley and Portage Pass: Alaska Geological Society, 46 p.

Mayo, L.R., Zenone, C., and Trabant, D.C., 1977, Reconnaissance hydrology of Portage Glacier basin, Alaska: U.S. Geological Survey Hydrologic Investigations Atlas HA-583, 2 sheets.

Meier, M.F., and Post, Austin, 1987, Fast tidewater glaciers: Journal of Geophysical Research, v. 92, No. B9, p. 9051-9058.

Schmidt, R.A.M., 1961, Recession of Portage Glacier, Alaska, in Geological Survey research 1961: U.S. Geological Survey Professional Paper 424-D, p. D202-D203.

Trabant, D.C., Krimmel, R.M., and Post, Austin, 1990, A preliminary forecast of the advance of Hubbard Glacier and its influence on Russell Fjord, Alaska: U.S. Geological Survey, Water-Resources Investigations Report 90-4172, 34 pp.

Trabant, D.C., Krimmel, R.M., Echelmeyer, K.A., Zirnheld, S.L., and Elsberg, D.H., 2003, The slow advance of a calving glacier: Hubbard Glacier, Alaska, U.S.A.: Annals of Glaciology, Volume 36, Number 1, pp. 45-50(6).

Ben W. Kennedy, Dennis C. Trabant, and Lawrence R. Mayo

\section{For further information contact:}

\section{U.S. Geological Survey \\ Alaska Science Center 4230 University Drive \\ Suite 201 \\ Anchorage, AK 99508-4664}

Or visit the USGS Alaska Science Center homepage on the World Wide Web at: http://alaska.usgs.gov/ 